\title{
Construction and Practice of Comprehensive Quality Control System for Undergraduate Education
}

\author{
Li Yang \\ School of Electrical Engineering \& Information \\ Northeast Petroleum University \\ Daqing, China \\ 19696163@qq.com
}

\author{
Keyong Shao \\ School of Electrical Engineering \& Information \\ Northeast Petroleum University \\ Daqing, China \\ 1783811235@qq.com
}

\begin{abstract}
Controlling of teaching quality is the core of college management. To construct a quality control system for teaching practice plays a significant and practical role in deepening college education reform and improving the quality of college education. Based on new development and internal management reform, our college explored in establishing a quality control system for teaching practice and has made certain progress.
\end{abstract}

Keywords-college; undergraduate education; overall quality management

\section{INTRODUCTION}

The quality of teaching practice is essential to college development. Controlling of teaching quality aims at proving current achievement, and more importantly, improving training outcomes continuously to meet the need of society as well as realize "dynamic management" and "gradual improvement" of teaching quality. The quality control system for college teaching practice is a full range of system and also an effective mechanism to improve teaching quality of college education. Lately, China's colleges have made a series of fruitful exploration in this area, but still have more work to do towards establishing a scientific and comprehensive teaching quality control system [1]. The author suggests, colleges ought to establish a diversified and full range of teaching quality control system, which includes internal guidance, incentive mechanisms, external inspection and evaluation system. These three sub-systems will help promote college teaching quality from different aspects.

\section{THE IMPORTANCE Of ESTABLISHING TEACHING QUALITY FROM DIFFERENT ASPECTS}

\section{A. Improving teaching quality is an urgent task of deepening college education reform.}

With the expansion of enrollment, colleges are facing the shortage of leading professors and education investment, which affect the stability and improvement of college education. Therefore, to effectively improve teaching quality has become an urgent task for college management [2].

\section{B. The quality control system of teaching process is irreplaceable in improving college teaching quality.}

The system is a full range and effective mechanism, which guarantees the improvement of teaching quality in colleges. From the management perspective, establishing and operating of the quality control system has various positive effects: first, the system can timely accumulate feedbacks from every aspect of teaching process; second, the system is able to evaluate teaching quality objectively; third, the system can restrain or inspire different members with the help of various assessment tools; fourth, the system can help enhance teaching quality continuously and guide teaching process to a beneficial cycle; fifth, the system can further promote the management of teaching quality so that it becomes more standard, routine and scientific.

\section{CONSTRuction Of TOTAL Quality CONTROL SyStem}

The ideal of total quality control is shown in the following aspects: first, it considers users as the central part, and makes the products fully satisfy users' demand in terms of product quality and service quality; second, it emphasizes prevention, and tends to eliminates quality threats before it emerges; third, it utilizes scientific methods to establish a strict quality control system, in order to implement whole process management; fourth, it promotes continuous quality improvement; fifth, it emphases the role of people[3]. Total quality control is the quality control of whole process, demanding all members to participate and various technologies. A set of comprehensive and effective mechanisms must be in place in order to promote total quality control. Accordingly, standards, guidance, procedures, responsibilities, quality assessment and feedbacks are also need to be established. As for personnel training, quality control is to manage the training purposes, standards, plans, process controls, responsibilities as well as quality inspection and feedbacks. The system of quality control is for the purposes of improving qualities [4]. 


\section{PRACTICE OF TEACHING QUALITY CONTROL IN OUR COLLEGE}

\section{A. Establishing teaching quality control system}

According to the comprehensive analysis of four elements of the quality management system, teaching executive duties include: the formulation rules and regulations, Improvement of the evaluation index, establishment of evaluation system, the implementation of supervision and inspection, establishment of evaluation system, the implementation of supervision and inspection, the establishment of standardized teaching, installation of organization model, responsibility of teaching supervisors, effective and rational allocation of power, the demand of talents training and teaching organization and management process design. Resource management responsibilities include: teachers, teaching materials, books and information, experimental teaching conditional, teaching funds, students living facilities, political and ideological education of students, campus culture, sports training facilities; The teaching process is the implementation of all the teaching links including specialty, recruitment, training, students graduate employment; The teaching quality and teaching reform is a response to feedback and evaluation of the social teaching of college education quality and make adjustments and innovation, adapt to the changes in the development of talents training requirements and objectives[5].

In the factors of quality management, management responsibility is the key element. In the teaching quality management, we must first establish reasonable and perfect management organization and responsibility system (see figure $1)$.



FIGURE I. RESPONSIBILITY SYSTEM DIAGRAM

Head of party and administration of university is the first responsibility for the quality of education and teaching, The headmaster in charge of teaching achieve the goal of teaching management through the role of functional departments. School should establish teaching instructional committee to research on major issues and decide the teaching management mechanism. The function of teaching management institutions should give full play to the functions of student work, office of academic affairs office and other departments in teaching management system, in school (department) level teaching management mechanism. Dean is responsible for the overall quality of teaching faculties' primary responsibility. Vice president in charge of teaching (deputy director) presides over the daily work. School (department) teaching committee is the study of the teaching management, consulting and decisionmaking body. School (department) teaching office deals with daily teaching administration and engages in the teaching status and quality information investigates work. Teaching and research section (group) undertake and complete the teaching task of teaching plan, develop teaching research and teacher training. They improve, supplement, adjust suggestion and assign the task to strengthen the basic construction of laboratory, library and so on.

\section{B. Standardizing teaching inspection management}

Teaching inspection management includes teaching preparation examination, the mid-term examination, paper selective examination and graduate design checks, The midterm teaching inspection is the key, Check the content as follows: the teaching link, organization and management of conventional teaching, teaching and research activities in education reform, the establishment of college teaching files and archives. Inspection methods include School selfexamination and the way the school checks. After the check, colleges must carefully write mid-term teaching inspection summary and submitted to the office, According to the advantages and disadvantages of teaching work, after a comprehensive summary, dean will report to school leadership. By mid-term examination teaching, teaching management department will have an overall understanding of the teaching situation, in order to improve future teaching and management work.

\section{Establishing undergraduate tutorial system to improve guidance for students}

In academic terms, the school must establish undergraduate tutorial system, The primary duties of undergraduate instructors is to introduce the professional characteristics, developments and social needs, combined with professional training objectives, to help students correct attitude towards learning, stimulate enthusiasm of learning objectives, to help students correct attitude towards learning, stimulate enthusiasm of learning and establish professional thinking.

Instructors should be familiar with each student to be guided, multifaceted understand students' interests, hobbies, strengths, learning dynamics, learning, intelligence and ability levels, According to the specific circumstances of the students, the teacher should guide students to learn to develop a reasonable plan, and guide students to carry out social practice and scientific research. Schools should employ above of teachers as undergraduates mentors. Schools should strengthen education v training and management of mentors in order to supervision and to accomplish goals dutifully. 


\section{Establishing teaching records system to enhance classroom management and ensure normal teaching process}

Classroom teaching is the main form of curriculum teaching. Success and failure of course teaching quality depends largely on the classroom teaching. So school teaching management departments must strengthen classroom management. Within two weeks of the new semester academic affairs should announce class timetable in publicity column of teaching building, indicate professional, curriculum, teacher, grade and so on. On the one hand teaching supervision and inspection is facilitated; on the other hand, students can choice study rooms expediently. Under the conditions of credit, because students' free elective curriculum, the traditional unit of professional teaching grades is discrete relatively, a professional grade counselor is inconvenience for the students' attendance check. So school should implement classroom recording system, classroom teacher or monitor is responsible for classroom teaching and reflects the content of classroom teaching and student attendance. Duty monitors or class representative will teaching secretary classroom teaching record for future reference.

At the end of each semester, teaching unit should collect teaching record for a binder and bind in a volume, as the basis of teacher's teaching workload evaluation and statistics. The students' attendance will report department as a reference for assessment of student learning. In the operation process of teaching, because of illness or things, the teacher need mediation class, the teacher must submit an application the day before teaching, with the approval of the departments in charge of teaching head, Teaching secretary is responsible for informing students mediating class decided. Due to unified organization related activities of the school to need mediation class, Academic affair is responsible for notifying relevant departments, and notifying the students by various departments. Mediation class situation and all other related to the teaching circumstances shall be loaded into classroom records.

\section{E. Innovation of incentive system}

Incentive system of award activity in each link of teaching needs to be established. In order to motivate teachers to actively undertake teaching work, make the school always stay at a high level of job of teaching and improve teaching quality. The school should organize regular excellent teaching plans, young teachers teaching competition and the selection of teaching quality excellence award in the first place. In the second place, school should select excellent practice team and outstanding instructor award of graduate design thesis per academic year. In addition, institutes of higher education should Periodic select teaching masters, outstanding teachers, teaching management cadres and excellent teaching and research laboratory director and so on. Through the implementation of these incentives, can greatly stimulate the enthusiasm of all the teachers teaching and promote the steady improvement in the quality of undergraduate teaching.

\section{F. Improving guidance for young professors to enhance their teaching skill}

1) Organization of the course teaching. Each department should establish peer-teaching course and organize new teachers and related teachers learn course. Course teachers are usually those who get various teaching awards or teaching evaluation score of excellent teachers. each department manager organize the master teacher and class teacher for serious discussion and exchange to promote mutual learning between the teachers, in order to improve the teaching quality.

2) Hold teachers' basic skills competition. The purpose of basic skills competition is to strengthen learning and take concrete actions to promote the teaching level. The young teachers take an active part in competition, undergo strict training and the inspection examination, The teacher's teaching level has been greatly improved through communication, observing and learning.

3) Improve the teachers' award. In order to encourage the teachers to study teaching contents and teaching methods, strengthen the guidance of young teachers for improving teaching quality completely. Teacher quality award is given every two years and young teacher award is awarded annually. Trough teaching award activity set up high-quality teaching model, teaching love their work and always put their heart and soul into it.

4) Encourage education reform teaching and research work. Encourage teachings in teaching self-examination and research; simultaneously, fuel the studying development and originality. Achieving funding increases for the teaching reform project, teaching reform project set up according to the core of the reform of teaching research, teaching communication to improve the teaching level.

5) Develop our on-job training. Take the way of personalized training for teachers. Support and encourage the teachers continuing professional education and teaching for improving teachers' professional quality and teaching ability; Take the advantages of invited elite professors, allowing interested professional quality and teaching ability; Take the advantages of invited elite professors, allowing interested professors to assistant in teaching so that they can learn from elite professors directly and improve their own teaching skills.

\section{G. Promote innovative teaching methods and tools}

Reform of teaching methods and tools needs to be actively promoted. The teaching process should focus on the students, in order to realize the transformation from teaching to practicing and create teaching methods that benefit the healthy development of students' individual consciousness, spirit and abilities. Teachers need to carry out research style teaching and interactive teaching, encourage students to think independently and challenge authorities, and try to incorporate students' interaction into teaching and convert passive learning to active learning and exploration. They should also set up open, exploratory and research related experiments, practicing 
courses as well as curriculum design courses, to help develop students' independency and innovative abilities. In addition, teachers need to develop teaching programs that relate to science and technology innovation, and establish students' technical training fields to carry out a full range of science and technology innovation activities. Meanwhile, institutes of higher education should provide students with more teamwork and independent research opportunities, and establish various education modules to train innovative people based on their individual characteristics.

\section{SUMMARY}

All in all, teaching quality control of colleges is a systematic project. Colleges have to construct a sound teaching quality control system that is based on their actual situation and follows the new development of college education. Such system can eventually help improve college teaching quality and cultivate more qualified people meeting the needs of society.

\section{ACKNOWLEDGMENT}

This research was financially supported by the Key Topic of Heilongjiang Province of China (Grant NO.GBB1212018)

\section{REFERENCES}

[1] B. Zhang, N. Wei, and L. Gao, "Analysis Bilingual Teaching Model and Teaching Quality Assessment Index System," 2010 2nd International Symposium on Information Engineering and Electronic Commerce, Ternopil, Ukraine, pp. 400-403, (2010).

[2] $\mathrm{Xu}$ jiandong,Wang haiyan, $\mathrm{Hu}$ zong. "On the innovation of open experiment management mode in colleges and universities," Experimental Technology and Management,2009, vol.26, No.2, pp.2226.

[3] Han Furong, Management Science Of Modern Quality, Mechanical Industry Press, pp2, August 2007

[4] Liming Yang, Yansong Xue. "Modern Teaching Quality Management concepts and Innovations of Management System," 2010 International Conference on E-Health Networking,Digital Ecosystems and Technologies,pp.228-231

[5] So Young Sohn *, Yong Han Ju.Conjoint analysis for recruiting high quality students for college education,"Expert Systems with Applications 37 (2010) 3777-3783 